\title{
Challenge of Teaching Genetics at Early Stage
}

Edwards Willey, Fuzhou Wang

Group of Neuropharmacology and Neurophysiology, Division of Neuroscience, The BASE, Chapel Hill, NC 27510, USA

"I cannot teach anybody anything. I can only make them think."

- Socrates

\begin{abstract}
$\Delta$ $\mathrm{S}$ a part of early science education, biogenetics is one of the critical components. Usually, the course is taught at the middle school at the earliest (Committee on the Science of Children Birth to Age 8, 2015). There may be specific difficulties for adolescent students who are first exposed to genetics knowledge, from cognition to knowledge reserve. In addition, understanding its basic concepts may require the lecturer to adopt certain methods and skills (Hirsh et al., 2020). Due to the abstract nature of genetics, this is more challenging for students of this age.
\end{abstract}

As far as genetics teaching is concerned, it is challenging for higher professional academic education (such as medical students and dental students, etc.) (Shirani Bidabadi et al., 2016). Of course, this is especially true for middle and high school students. Kılıç Mocan (2021) observed the understanding of basic genetics knowledge of high school students in his school through an interview. It turned out that many students are unfamiliar with its concepts and fail to clarify the relationship between the basic concepts, causing mutual confusion. This result is understandable. This is true among beginners and happens in the early stages of learning among professional students (Dudlicek et al., 2004; Monsen, 1999; Telner et al., 2008).

Human cognition of things is a gradual process (Sanders, 2013). Age is one of the crucial factors affecting cognition (National Research Council (US) Panel to Review the Status of Basic Research on School-Age Children, 1984). We cannot overcome the influence of age on the perception of things. However, under the same conditions and background, the methods of acquiring knowledge can be very different, and their results will also vary greatly. Of course, this difference in learning efficiency due to methodological differences is exceptionally related to the person's knowledge level, the teaching methods they use, and the teaching conditions their institution provides (Değirmencioğlu, 2021; Jungert \& Rosander, 2010; Sharp et al., 2016). For 


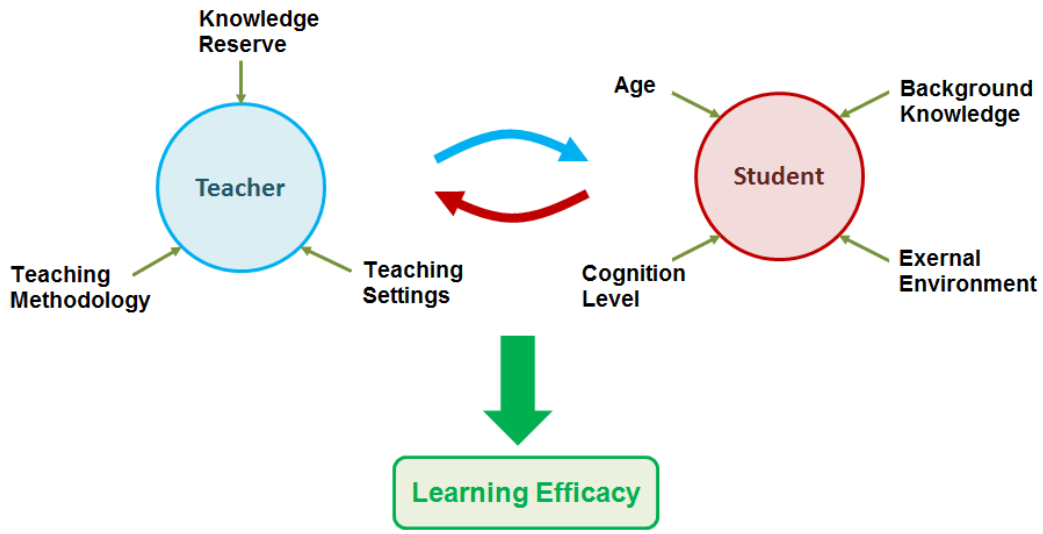

Figure 1. Teacher-Student Interactive Relationship.

example, suppose a highly knowledgeable teacher has a blunt and uninspired teaching method and only instills knowledge points into the students or lets them memorize by rote. In that case, one can imagine how their teaching effect will be.

In the same way, a teacher may lack some knowledge reserves, but his teaching methods can arouse students' sympathy and interest. This undoubtedly enables students to grasp the concepts and relationships among their learned points quickly. Therefore, regardless of the subject, students' cognition and mastery of knowledge result from a number of factors that comprehensively function. Of course, the teaching of genetics is with no exception. Teaching is ultimately a comprehensive result of the software and hardware interaction of various aspects such as students, teachers, and the environment (Figure 1).

\section{References}

Committee on the Science of Children Birth to Age 8: Deepening and Broadening the Foundation for Success; Board on Children, Youth, and Families; Institute of Medicine; National Research Council; Allen LR, Kelly BB, editors. (2015). Transforming the workforce for children birth through age 8: A unifying foundation. Washington (DC): National Academies Press (US); 2015 Jul 23. 4, Child Development and Early Learning. Available at: https://www.ncbi.nlm.nih.gov/books/NBK310550/

Değirmencioğlu, Ü. (2021). The impact of teacher self-efficacy on teaching techniques: Traditional or contemporary? European Journal of English Language Teaching, 6(3):201-216. DOI: http://dx.doi.org/10.46827/ejel.v6i3.3662 
Dudlicek, L.L., Gettig, E.A., Etzel, K.R., \& Hart, T.C. (2004). Status of genetics education in U.S. dental schools. Journal of Dental Education, 68(8):809-818.

Hirsh, Å., Nilholm, C., Roman, H., Forsberg, E., \& Sundberg, D. (2020). Reviews of teaching methods - Which fundamental issues are identified? Education Inquiry, In press. DOI: http://dx.doi.org/10.1080/20004508.2020.1839232

Jungert, T., \& Rosander, M. (2010). Self-efficacy and strategies to influence the study environment. Teaching in Higher Education, 15(6):647-659. DOI:

http://dx.doi.org/10.1080/13562517.2010.522080

Kılıç Mocan, D. (2021). What do students really understand? Secondary education students' conceptions of genetics. Science Insights Education Frontiers, 10(2):14051422. DOI: $\underline{\text { http://dx.doi.org/10.15354/sief.21.or061 }}$

Monsen, R.B. (1999). State of the art: Interdisciplinary collaboration for health professional education in genetics. Biological Research for Nursing, 1(2):119-121. DOI: http://dx.doi.org/10.1177/109980049900100209

National Research Council (US) Panel to Review the Status of Basic Research on SchoolAge Children; Collins WA, editor. (1984). Development during Middle Childhood: The Years from Six to Twelve. Washington (DC): National Academies Press (US); Chapter 3, Cognitive Development in School-Age Children: Conclusions and New Directions. Available at: https://www.ncbi.nlm.nih.gov/books/NBK216774/

Sanders, R.A. (2013). Adolescent psychosocial, social, and cognitive development. Pediatrics in Review, 34(8):354-358; quiz 358-359. DOI: http://dx.doi.org/10.1542/pir.34-8-354

Sharp, A.C., Brandt, L., Tuft, E.A., \& Jay, S. (2016). Relationship of self-efficacy and teacher knowledge for prospective elementary education teachers. Universal Journal of Educational Research, 4(10):2432-2439. DOI: http://dx.doi.org/10.13189/ujer.2016.041022

Shirani Bidabadi, N., Nasr Isfahani, A., Rouhollahi, A., \& Khalili, R. (2016). Effective teaching methods in higher education: Requirements and barriers. Journal of Advances in Medical Education \& Professionalism, 4(4):170-178.

Telner, D.E., Carroll, J.C., \& Talbot, Y. (2008). Genetics education in medical school: A qualitative study exploring educational experiences and needs. Medical Teacher, 30(2):192-198. DOI: http://dx.doi.org/10.1080/01421590701827353

Correspondence to: Edwards Willey, Ph.D. E-mail: edwards.willey@basehq.org

Fuzhou Wang, M.D., Ph.D. E-mail:fred.wang@basehq.org Group of Neuropharmacology and Neurophysiology Division of Neuroscience

The BASE

Chapel Hill NC 27510 